\title{
Benlafaxinaren eragina ezegonkortasun sozial kronikoa jasandako sagu emeen sistema serotoninergiko zentralean eta jokabidean
}

\author{
Effects of venlafaxine on the central serotoninergic system and behavior of \\ female mice subjected to chronic social instability stress
}

Ainitze Labaka, Eneritz Gómez-Lázaro, Olatz Goñi-Balentziaga, Aitor Renteria-Dominguez eta Larraitz Garmendia.

Oinarrizko prozesu psikologikoak eta haien garapena, Psikologia Fakultatea, Donostia. Euskal Herriko Unibertsitatea (UPV/EHU)

ainitze.labaca@ehu.eus

\section{Laburpena}

Bi bider ohikoagoa da depresioaren diagnosia emakumeengan gizonezkoetan baino, eta, ondorioz, baita farmako antidepresiboen erabilera ere. Hala ere, estresarekin lotutako nahasteen eta haien tratamenduaren inguruko ikerketa gehienak animalia arretan egiten dira, eta ikerketetako emaitzak gizon nahiz emakumeetara orokortzen dira gero. Ildo horretatik, antsietatearen eta depresioaren aurkako tratamenduen eraginkortasuna sexuaren araberakoa da, berezitasun biologikoak izaki. Hori dela-eta, lan honek ezegonkortasun sozial kronikoaren estresa bizi duten sagu emeen jokabidean eta garuneko bide serotoninergikoan benlafaxinak -serotoninaren eta noradrenalinaren birkaptazioaren inhibitzailea- duen eragina du aztergai.

Gako-hitzak: emeak, estresa, jokabidea, benlafaxina, depresioa.

\section{Abstract}

Women are twice as likely as men to develop depression, and are also more frequently prescribed antidepressant treatments. This sexual disparity is also observable in effectiveness of treatments. Despite this fact, most studies that have used animal models to determine the physiological mechanisms implicated in depression and to develop specific drugs for their treatment have been performed in males. The aim of this study was to analyze the effects of the serotonine and noradrenaline reuptake inhibitor venlafaxine on the behavior and central serotoninergic pathways of female mice subjected to chronic social instability stress.

Keywords: female, stress, behavior, venlafaxine, depression 


\section{Sarrera eta helburuak}

Azken urteotan, estresari lotutako nahasteen artean, depresioaren intzidentzia eta prebalentziaren gorakada bereziki nabarmena izan da. Depresioa XXI. mendeko burunahasterik ohikoena da, eta munduan 359 milioi pertsona inguruk pairatzen dutela estimatzen da. Jasaten duenari eragiten dion kalte handia dela-eta, gaur egun, munduko ezgaitasun-kausa \% 20-25 emakumeetan eta \% 7-12 gizonezkoetan, hain zuzen (2). Datu horiek, faktore sozialez gain, sexu-ezberdintasun biologikoek azal ditzakete. Horrela bada ere, nahastearen inguruko ikerlan gehienak animalia arrekin soilik egiten dira (3). Hain zuzen ere, zenbait datu-base eta aldizkariren arabera, neurozientziaren eta biomedikuntzaren alorrean argitaratzen diren artikulu guztien artean, laurdenak soilik erabiltzen ditu subjektu emeak $(4,5)$. Baina ar eta emeen fisiologia ezberdina da, eta arretan jasotako emaitzak emakumeei orokortzea ez da egokia. Izan ere, farmako antidepresiboak emakumeengan ez dira gizonezkoengan bezain eraginkorrak (6) eta, oro har, emakumeek farmakoen ondorio kaltegarriak jasateko \% 50-75eko aukera handiagoa dute (7).

Estresari lotutako nahasteak animalia-ereduen bidez luze ikertu badira ere, datu gutxi dago gaur egun emeen inguruan. Izan ere, emeen ernal-zikloari lotutako hormonen gorabeherek gainerako aldagai fisiologiko eta jokabide-aldagaiak eragin ditzaketela pentsatu izan da, eta, ondorioz, subjektu emeak erabilita jasotako emaitzen bariantza zabalagoak emaitzen baliozkotasuna murriztu zezakeela. Baina azken urteotan egindako ikerketen arabera, emeek ernal-zikloko fase batetik bestera duten aldakortasuna ez da arrek egun batetik bestera dutena baino handiagoa (8). Bestalde, ikerkuntzan subjektu emeak luzaroan baztertu izan direnez, gaur egun ez dago emeetan estres soziala aplikatzeko prozedura estandarrik. Izan ere, sagu emeak ez dira territorialak, eta arretan estres soziala eragiteko finkatutako lehiakortasun territorialaren prozedurek ez dute emeetan estres-erantzuna pizten. Ildo horretatik, Herzog eta lankideek (2009) arratoietan eta Schmidt eta lankideek (2010) saguetan proposatutako ezegonkortasun sozial kronikoaren estres-ereduak egokiagoa dirudi sagu emeetan estresari lotutako nahasteak ikertzeko. Hain zuzen ere, aurreko lan batean, lau astez ezegonkortasun sozial kronikoa aplikatzeak sagu emeen plasmako kortikosterona-maila igo eta depresiomotako anhedonia jokabidea eta aldaketa fisiologikoak eragin zituela aurkitu genuen (11).

Zentzu horretan, depresioaren hipotesi monoaminergikoaren arabera, depresioa garunean serotonina (5HT), noradrenalina (NA) eta dopamina (DA) maila baxuak daudenean garatu daiteke. Monoamina horien neurotransmisioa gogo-aldarte eta motibazioarekin lotzen dira, besteak beste. Bereziki, 5HTren parte-hartzea azpimarratu izan da depresioaren agerpenean; izan ere, estres-erantzunean sistema serotoninergikoa aktibatzen dela ikusi da, eta serotoninaren birkaptazioaren inhibitzaileak diren farmakoek efektu antidepresiboa dute (1214). Hala ere, sintomen erremisio-ratio eta eraginkortasun handiagoa erakutsi dezakete mekanismo bat baino gehiago duten farmakoek. Kasurako, benlafaxina, hau da, serotonina eta noradrenalinaren birkaptazioaren inhibitzailea den antidepresiboa, gehien preskribatzen denetarikoa da (15).

Hori guztia kontuan izanda, lan honek bi helburu nagusi ditu:

Batetik, ezegonkortasun sozial kronikoaren estresak sagu emeen gorputz-pisuan, aktibitate serotoninergiko zentralean ( $5 \mathrm{HT}$ eta haren $5 \mathrm{HIAA}$ metabolitoan) eta jokabidean sortzen dituen aldaketak aztertzea.

Bestetik, asaldura horiek benlafaxina farmako antidepresiboarekin leheneratzen diren behatzea. 


\section{Material eta metodoak}

\subsection{Diseinu esperimentala}

Laurogeita hamasei sagu eme hirunaka jarri genituen astebetez laborategiko baldintzetara ohi zitezen. Ondoren, saguen erdiek $(n=48)$ hirunaka jarraitu zuten kontrol-taldea osatzeko, eta beste erdiei $(n=48)$ ezegonkortasun sozial kronikoa aplikatu zitzaien: Hiru egunez saguak launaka jartzen ziren, eta laugarren eguna isolatuta pasatzen zuten. Prozesu hori behin eta berriz errepikatu zen. Launaka jartzen ziren bakoitzean, ezezagunak zitzaizkien kaiolakideak esleitzen zitzaizkien. Era horretan, emeek ezin zuten sare sozial egonkor bat osatu. Ondoren 32. egunetik hasita, kontrol zein estresatuen erdiei $(n=24)$ benlafaxina farmakoa txertatu zitzaien ( $20 \mathrm{mg} / \mathrm{kg}$, peritoneo barnean) egunero hiru astez, eta beste erdiei serum fisiologikoa. Azkenik, azpitalde bakoitzeko 12 na saguk jokabide-testak egin zituen, eta gainerakoak parametro biologikoak neurtzeko sakrifikatu ziren (ikus 1. irudia).

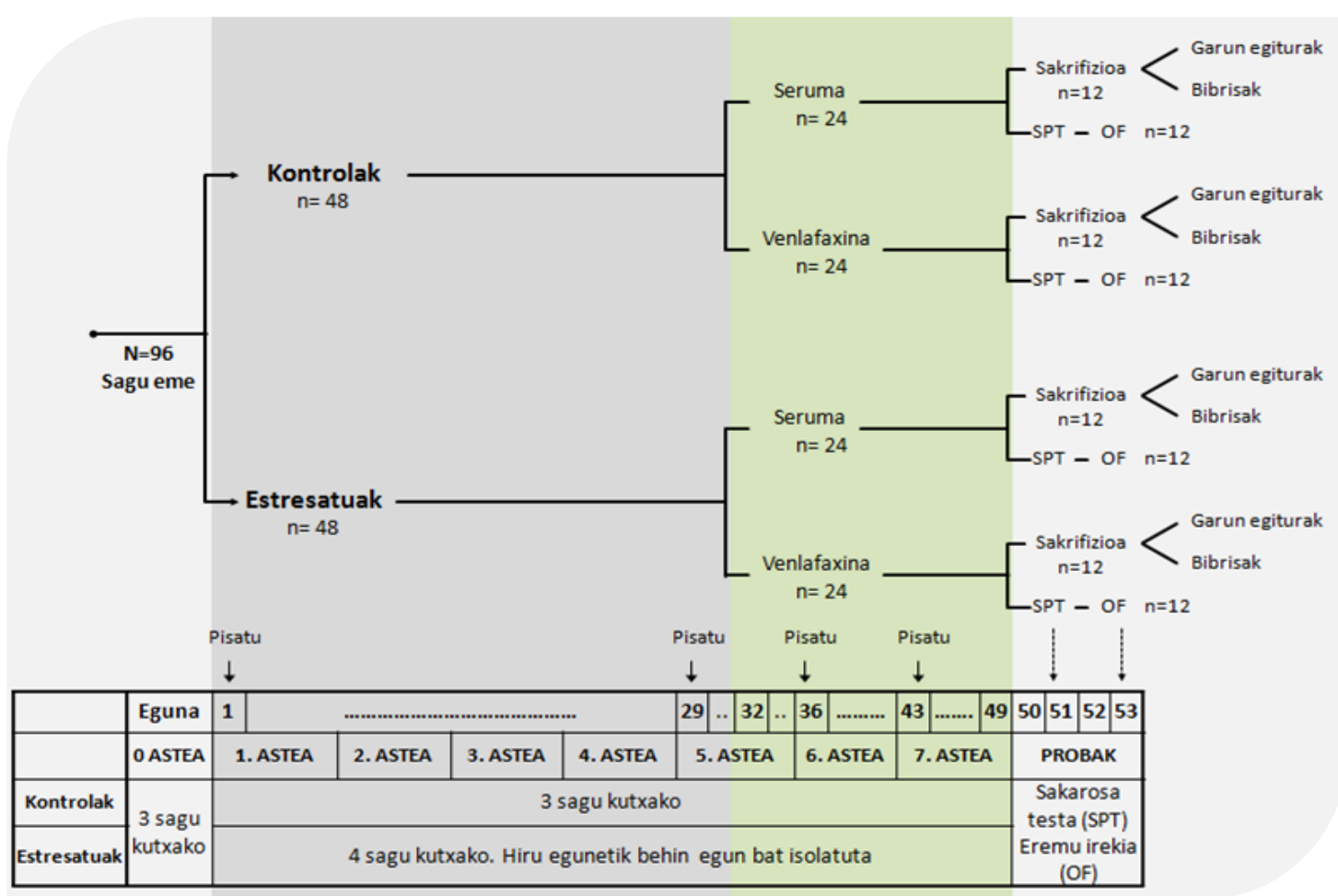

1. irudia. Diseinu esperimentala. Animalien ongizaterako Euskal Herriko Unibertsitateko Batzorde Etikoaren (AEEB) onespena du esperimentu honek.

\subsection{Jokabide-probak}

Hiru jokabide mota aztertu ziren esperimentu honetan. Lehenik, anhedonia jokabidea behatu zen. Anhedonia plazera sentitzeko ezintasunari edo berez atsegingarri diren estimuluen aurrean interesik ez izateari deritzo. Depresio-sintomatzat hartzen da, eta animalietan sakarosaren lehenestea (sucrosse preference test, SPT) behatuz aztertzen da. Saguei bi edalontzi jartzen zaizkie aukeran, bata sakarosadun urarekin eta bestea ur hutsarekin. Depresio-zantzua duten saguek ur gozo gutxiago edan ohi dute.

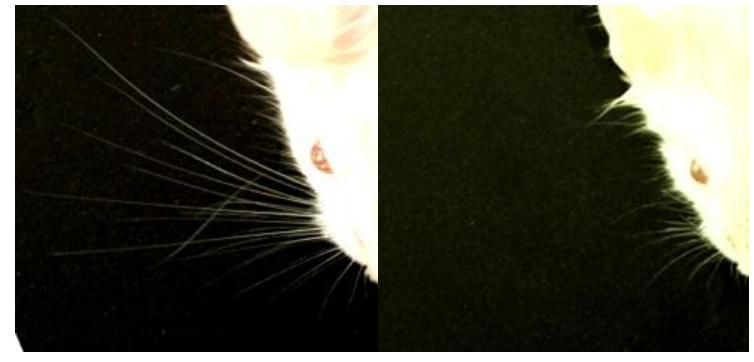

2. irudia. Barbering jokabide-zeinuak. Ezkerrean, bibrisak osorik dituen sagua. Eskuinean, bibrisak moztu dizkioten sagua. 
Bigarrenik, barbering jokabidea aztertu zen. Jokabide hori saguek bata bestearen muturreko bibrisak hortzekin moztean datza (ikus 2. irudia). Saguen muturreko bibote edo bibrisek berebiziko garrantzia dute saguen biziraupenerako, haien bidez inguruko bibrazioak jaso eta inguruko informazioa prozesatzen baitute. Barbering jokabidea antsietatearekin eta hierarkia soziala finkatzeko lehiarekin erlazionatzen da sagu emeetan (16).

Azkenik, eremu irekiko proban (ingelesez open field test, OF), saguak kutxa zabal batean ipintzen dira eta bertan nahieran ibiltzen uzten zaie. Bertan, subjektuen jarduera lokomotorra neurtzen da. Gelditasuna depresioarekin lotzen da, eta kutxako ertzetan ibiltzea -hormaren babespean, alegia - antsietatearekin erlazionatzen da.

\subsection{Neurketa fisiologikoak}

Subjektuen hipokanpo eta kortex prefrontaleko $5 \mathrm{HT}$ eta $5 \mathrm{HIAA}$ mailak bereizmen handiko kromatografia likido bidez neurtu ziren (ingelesez High Performance Liquid Chromatography, HPLC). Saguen gorputz-pisua esperimentuaren hasieran, amaieran, eta tarteko hiru egunetan erregistratu zen.

\subsection{Analisi estatistikoak}

Analisi estatistiko guztiak Windowsentzako SPSS 22 programa erabiliz egin ziren eta esangura-maila $p<0.05$ ean finkatu zen $\left(\mathrm{p}<0.05^{*} ; \mathrm{p}<0.01^{* *} ; \mathrm{p}<0.001^{* * *}\right)$. Aldagai biologikoak eta jokabide-aldagaiak aztertzeko bi faktoreko ANOVA erabili zen, eta estresa eta farmakoa faktoreen arteko elkarrekintza kasuetan Post hoc testa, Bonferroniren irizpideari jarraiki. Bibrisen analisia egiteko, kontingentziataulak erabili ziren. Gorputz-pisuaren bilakaera aztertzeko lagin errepikatuen proba baliatu zen.

\section{Emaitzak}

\subsection{Estresaren eta benlafaxinaren eragina jokabidean}

Analisi unibarianteak erakutsi zuenez, estresatutako saguek sakarosa gutxiago edan zuten kontrolen aldean $\left(F_{[1,43]}=4.64 ; p=0,037\right)$. Benlafaxina antidepresiboa jasotako saguek ere serum fisiologikoa jasotakoek baino sakarosa gutxiago edan zuten $\left(F_{[1,43]}=13.76 ; p=0,001\right)$ (1. grafikoa). Ez zen elkarrekintzarik aurkitu estresa eta farmakoa faktoreen artean.
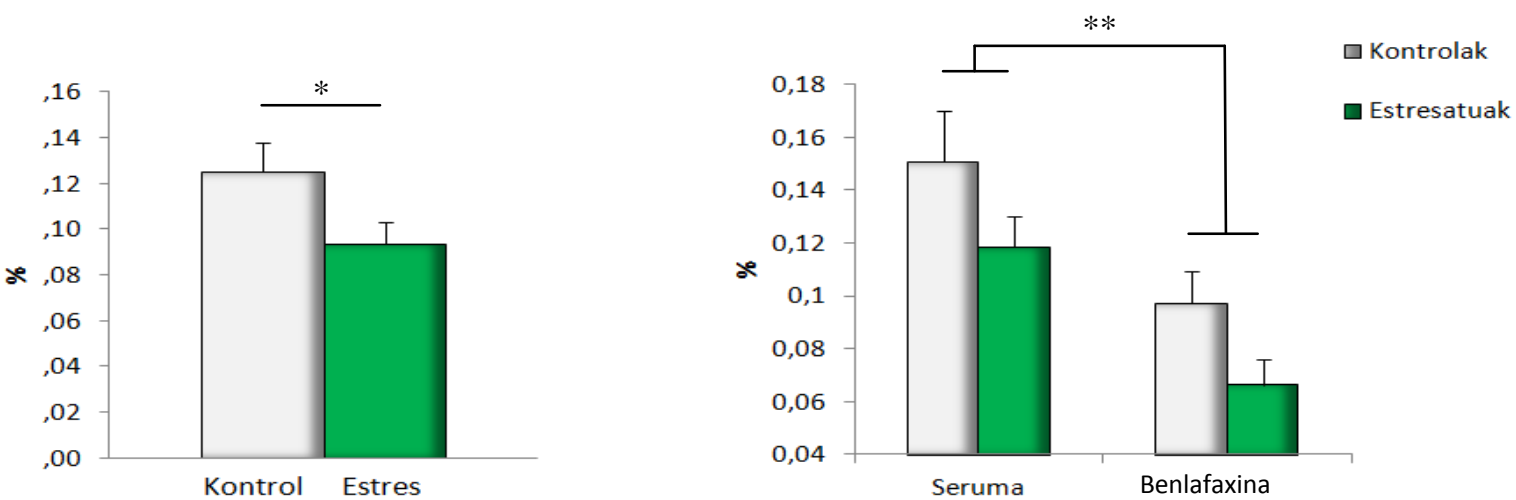

1. grafikoa. Sakarosa-kontsumoa gorputz-pisuarekiko proportzioan. Ezkerrean, kontsumoa kontrol-taldea eta estres-taldea bereizita. Eskuinean, subjektu berberak seruma edo farmakoa jaso izanaren araberako azpitaldetan bereizita. 
Barbering jokabidea aztertzean, estresatutako taldean aurkitutako bibrisa motzen portzentajea kontroletan aurkitutakoa baino handiagoa zela ikusi zen (Fisherren test zehatza, $p=0,044)(2$. grafikoa). Benlafaxinak ez zuen eraginik izan jokabide horretan.

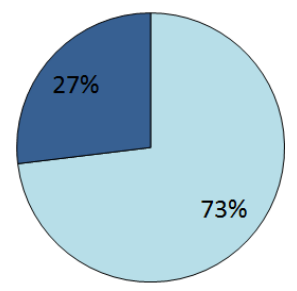

Kontrolak

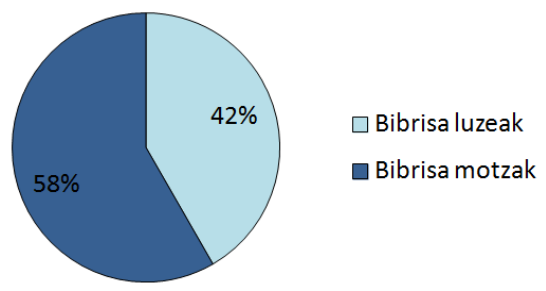

Estresatuak

2. grafikoa. Bibrisa luze eta motzen portzentajea kontrol-taldean $(n=24)$ eta estres-taldean $(n=24)$.

Eremu irekiko probari dagokionez, ez zen ezberdintasunik aurkitu mugitu gabe iragandako denboran, ez eta saguek ibilitako distantzian ere. Hala ere, eta estresak ezberdintasun esanguratsurik eragin ez bazuen ere, farmakoak saguek eremuaren erdialdean denbora gehiago pasatzea eragin zuen $\left(F_{[1,47]}=4.32 ; p=0,04\right)$ (3. grafikoa).

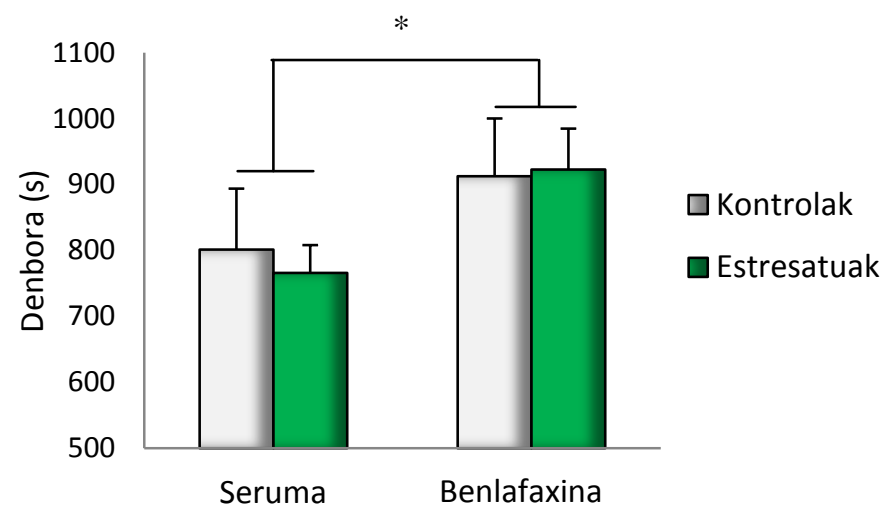

3. grafikoa. Eremu irekiko proban kaxaren erdialdean iragandako denbora estresaren eta farmakoaren araberako azpitaldeak alderatuta.

\subsection{Estresaren eragina gorputz-pisuan}

Estresak eragina izan zuen saguen pisu-bilakaeran. Lagin errepikatuentzako probak adierazi zuenez, sagu estresatuek ez zuten kontrolek bezainbeste pisu irabazi denboran zehar $\left(F_{[1,94]}=58.34 ; p=0.000\right)$. Benlafaxinak ez zuen aldaketarik eragin gorputz-pisuan (4. grafikoa).
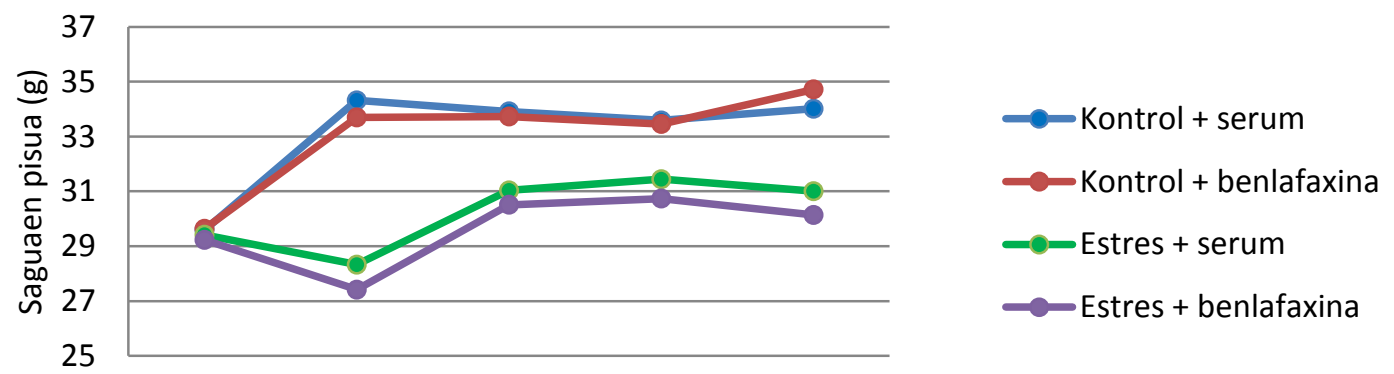

1. eguna 29. eguna 36. eguna 43. eguna 50. eguna

4. grafikoa. Saguen gorputz-pisuaren bilakaera esperimentuan zehar estresaren eta farmakoaren araberako azpitaldeak alderatuta. 


\subsection{Estresaren eta benlafaxinaren eragina kortex prefrontaleko bide serotoninergikoan}

Kortex prefrontaleko 5HIAA metabolito mailari dagokionez, analisi unibarianteak erakutsi zuen estresa eta farmakoa faktoreek kortex prefrontaleko 5HIAA mailan eragina izan zutela. Estresak 5HIAA maila igo zuen $\left(\mathrm{F}_{[1,47]}=14.88 ; \mathrm{p}=0.000\right)$, eta benlafaxinak ere norabide berean eragin zuen igoera $\left(F_{[1,47]}=4.32 ; p=0.017\right)$ (5. grafikoa). Hala ere, ez zen bi faktoreen arteko elkarreraginik aurkitu.
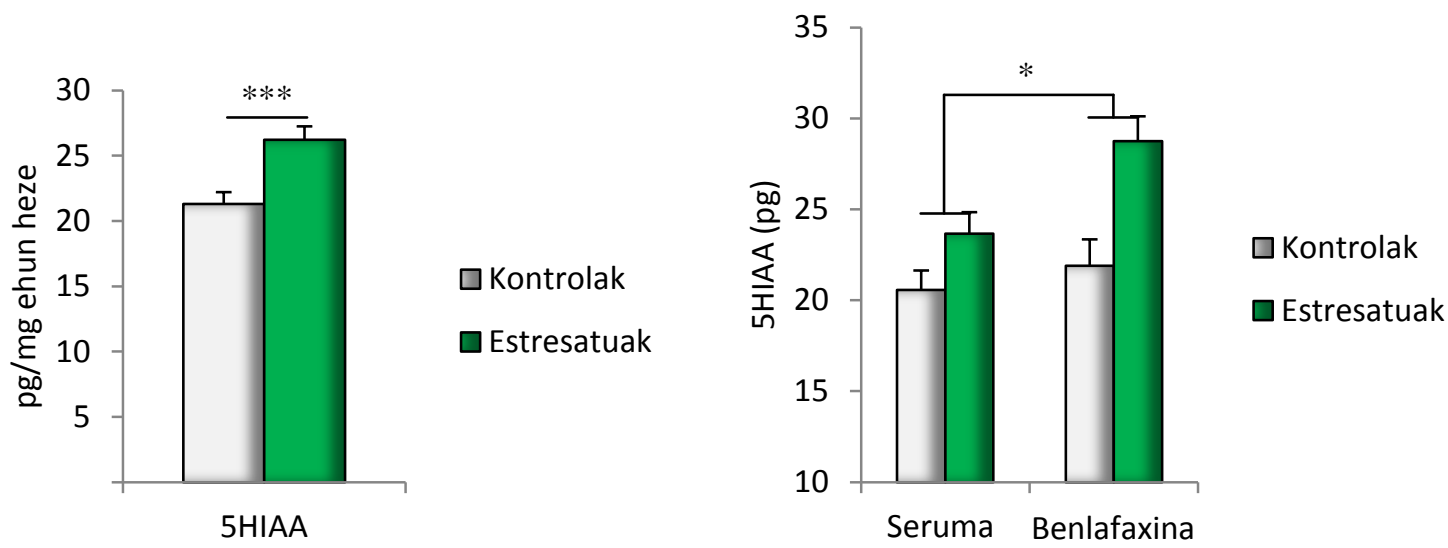

5. grafikoa. Serotoninaren 5HIAA metabolito-mailak kortex prefrontalean. Ezkerrean, kontrol-taldea eta estres-taldea bereizita. Eskuinean, subjektu berberak seruma edo farmakoa jaso izanaren araberako azpitaldetan bereizita.

\subsection{Estresaren eragina hipokanpoko bide serotoninergikoan}

Analisi unibarianteak adierazi zuenez, estresak hipokanpoko 5 HIAA maila murriztu zuen $\left(\mathrm{F}_{[1,49]}=4.44\right.$; $p=0.042)$, baita $5 H T$ maila ere $\left(F_{[1,49]}=6.8 ; p=0.012\right)$ (6. grafikoa). Benlafaxinak ez zuen eraginik izan hipokanpoko bide serotoninergikoan, eta estresa eta farmakoa faktoreek ez zuten elkarrekintzarik adierazi.

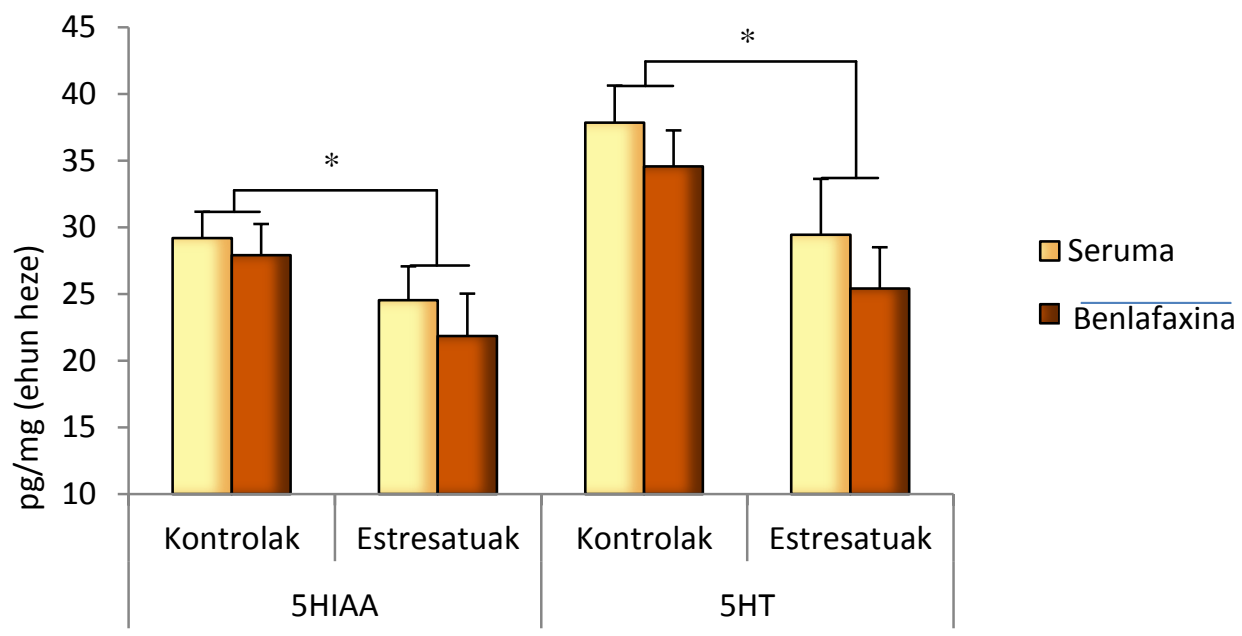

6. grafikoa. Hipokanpoko 5HIAA eta 5 HT mailak estresaren eta farmakoaren araberako azpitaldetan bereizita. 


\section{Ondorioak}

Emaitzei erreparatuta, zazpi asteko ezegonkortasun sozial kronikoaren estresak sagu emeetan depresio-motako sintomak eragin dituela esan dezakegu. Batetik, SPTn sakarosa-kontsumo murritzak anhedonia adierazten du talde estresatuan. Anhedonia depresioaren sintoma nagusitzat hartzen da, eta animalia zein gizakietan garuneko sari-sistema erasanean datza haren oinarri biologikoa. Espezieen arteko parekotasun hori dela medio, animalia-ereduetan zeinu depresiboak aztertzeko irizpide nagusitzat proposatu da (17). Gainera, hipokanpoko 5HT eta 5HIAA mailen gutxitzea bat dator depresioaren hipotesi monoaminergikoarekin, bide serotoninergikoko osagaien eskasia adierazten baitute. Kortex prefrontalari dagokionez, 5HIAA maila handiagoa adierazi dute subjektu estresatuek, nahiz eta $5 \mathrm{HTn}$ ezberdintasunik ez egon. Horrek, egitura honetan estresatuek kontrolek baino aktibitate serotoninergiko handiagoa dutela iradokitzen du. Nahaste psikiatrikoen bilakaeran, aktibitate monoaminergikoaren aldaketa-dinamika ezberdinak agertu daitezke garun-egitura batetik bestera (19). Bestetik, pisu gutxiago irabazi izanak adierazten du estresak saguetan eragin kaltegarria izan duela. Esperimentua hasi aurretik subjektu guztien pisua antzekoa bazen ere, esperimentuan zehar estresatutakoek pisua galdu dute, eta ostera, pisua hartzen hasi badira ere, ez dute kontrolek adina irabazi. Estresaldiko puntu bakoitzean neurtutako gorputz-pisua ere esanguratsuki ezberdina izan da taldeen artean. Bestetik, barbering zeinuen portzentajea handiagoa izan da talde estresatuan. Emaitza hori bateragarria da estres-ereduak saguei sare sozialak finkatzeko eragiten dien ezintasunarekin, kaiolakideei baliabideak kentzeko jokabide menderatzaile modura interpreta baitaiteke (16). Antsietate-zeinu modura ere hartu izan da barbering-a, estresak eragindako jokabide konpultsibo moduan (18). Baina antsietatea behatzeko erabiltzen den OF proban ez da kontrol eta estresatuen arteko alderik nabarmendu. Litekeena da farmakoa edo seruma emateko peritoneo barneko ziztadek kontrolei antsietate-zantzuak eragin izana, eta, hori dela-eta, OF proban bi taldeen artean ezberdintasun esanguratsurik aurkitu ez izana, baita sagu kontrolen pisu irabazia moteldu izana ere.

Benlafaxinari dagokionez, badirudi OF proban efektu antsiolitikoa izan duela, saguak eremuaren erdialdean kaxa-ertzeko hormen babesean baino gehiago ibili baitira. Hala ere, efektu hori kontrol-taldean nahiz estres-taldean eragin duela aipatu behar da, eta esperimentu honetan neurtutako gainerako aldagaietan ere ez dela estresa eta farmakoa faktoreen arteko elkarrekintzarik aurkitu. Benlafaxinak ez du, beraz, estresaren eragina lehengoratu. Gainera, farmakoak anhedonia eragin du, estresaren norabide berean. Emaitza honen harira, aurreko lan batean benlafaxinak arratoietan janari-kontsumoa murriztu zuela aurkitu zuten (20) eta benlafaxina hartzen duten pertsonen $\% 11 \mathrm{k}$ apetitu-galera pairatzen du (21). Hala ere, farmakoagatiko apetitu-galera hori nozitzen duten gehienek ez dute pisu-galerarik izaten. Era berean, gure esperimentuko saguen janari-kontsumoa murriztu badu ere, benlafaxinak ez du gorputz-pisuan eraginik izan. Kortex prefrontalean, berriz, benlafaxinak 5HIAA maila handitzea eragin du, eta farmakoa eta estresa faktoreen artean elkarrekintza esanguratsurik aurkitu ez bada ere, emaitza hau tentuz hartu beharrekoa da. Izan ere, 5. grafikoan ikus daitekeen moduan, benlafaxina jasotako sagu estresatuetan nabarmentzen da bereziki 5HIAA igoera.

Oro har, benlafaxinak ez du estresaren eragina arintzeko gaitasunik erakutsi lan honetan. Zentzu horretan, azpimarratzekoa da, batetik, emeen farmakozinetika ez dela arren berdina, eta benlafaxina erabilitako aurreko lan gehienak subjektu arrekin osatu direla. Bestetik, antidepresiboak probatzen dituzten ikerlan askok estresa hasi aurretik edo estres-aldia hastearekin bat ematen dituzte farmakoak. Ikerlan honetan, farmakoaren administrazioa estresak bere efektua egindakoan hasi da. Metodologia-ezberdintasun hori emaitza ezberdinen atzean egon daiteke, eta garrantzia handia du errealitate klinikora hurbiltzeko garaian. Izan ere, pertsonetan, antidepresiboak sintomak agertutakoan errezetatzen dira, eta ez lehenago (22).

Etorkizuneko ikerketei begira, ikerlan pilotu honetan estresak eta benlafaxinak $5 \mathrm{HTn}$ eta 5HIAAn izan duten eragina ikusita, interesgarria litzateke bide serotoninergikoaren ikuspegi 
zabalago bat lortzea, 5HTren aitzindari den triptofanoa eta haren bide metabolikoan onuragarriak (azido kinurenikoa) edo neurotoxikoak (3-hidroxikinurenina eta azido kinolinikoa) izan daitezkeen konposatuak aztertuz. Halaber, garun-egitura ezberdinetako NA maila ikertzeak estresaren eta benlafaxinaren efektuaren inguruko ikuspegi zehatzago bat eskainiko luke. Antsietate-motako jokabideei begira, farmakoa ziztatzeak eragin ditzakeen eragozpenak saihesteko, antidepresiboa ahoz ematea beste aukera bat izango litzateke. Hala ere, kontuan izan behar da printzipio aktiboen bioerabilgarritasuna aldakorragoa izan daitekeela subjektu batetik bestera aho bidez emanez gero.

\section{Eskerrak eta oharrak}

Ikerketa hau Eusko Jaurlaritzaren Ikertzaileak Prestatzeko 2014ko Doktoratu Aurreko Bekari eta Espainiako Ekonomia eta Lehiakortasun Ministerioaren proiektuari (PSI2015-63658-R) esker burutu da.

Egileek UPV/EHUko SGIkerren giza babesa eta babes teknikoa eskertzen dute

Eskerrik asko Joxeba Lizeaga Arostegi ingeniari eta lagunari, ezegonkortasun sozial kronikoan taldekatzerakoan subjektuak birritan elkarrekin ez egokitzeko diseinatutako konbinazioengatik.

\section{Erreferentzia bibliografikoak}

1. World Health Organization. Depression and other common mental disorders: global health estimates [Internet]. World Heal Organ; 2017 [Kontsulta: 2018-03-27]. Eskuragarri: http://apps.who.int/iris/bitstream/10665/254610/1/WHO-MSD-MER-2017.2-eng.pdf

2. Kessler RC, Gruber M, Hettema JM, Hwang I, Sampson N, Yonkers KA. Co-morbid major depression and generalized anxiety disorders in the National Comorbidity Survey follow-up. Psychol Med. 2008;38(3):365-74.

3. Johnson PA, Fitzgerald T, Salganicoff A, Wood SF, Goldstein JM. Why Women' s Health Can't Wait[Internet]. Brigham and Women's Hospital; 2014 [Kontsulta: 2018-03-27]. Eskuragarri: http://www.brighamandwomens.org/Departments_and_Services/womenshealth/ConnorsCente r/Policy/ConnorsReportFINAL.pdf.

4. Mogil JS. Perspective: Equality need not be painful. Nature. 2016;535(7611):S7.

5. Ritz SA, Antle DM, Côté J, Deroy K, Fraleigh N, Messing K, Parent L, St-Pierre J, Vaillancourt C, Mergler D. First steps for integrating sex and gender considerations into basic experimental biomedical research. FASEB J. 2014;28(1):4-13.

6. Dalla C, Pitychoutis PM, Kokras N, Papadopoulou-Daifoti Z. Sex differences in animal models of depression and antidepressant response. Basic Clin Pharmacol Toxicol. 2010;106(3):226-33.

7. Shah K, McCormack CE, Bradbury NA. Do you know the sex of your cells? Am J Physiol Cell Physiol. 2014; 306(1):3-18.

8. Prendergast BJ, Onishi KG, Zucker I. Female mice liberated for inclusion in neuroscience and biomedical research. Neurosci Biobehav Rev. 2014; 40:1-5.

9. Herzog CJ, Czéh B, Corbach S, Wuttke W, Schulte-Herbrüggen O, Hellweg R, Flügge G, Fuchs E. Chronic social instability stress in female rats: a potential animal model for female depression. Neuroscience. 2009;159(3):982-92.

10. Schmidt MV, Scharf SH, Liebl C, Harbich D, Mayer B, Holsboer F, Müller MB. A novel chronic 
social stress paradigm in female mice. Horm Behav. 2010;57(4-5):415-20.

11. Labaka A, Gómez-Lázaro E, Vegas O, Pérez-Tejada J, Arregi A, Garmendia L. Reduced hippocampal IL-10 expression, altered monoaminergic activity and anxiety and depressive-like behavior in female mice subjected to chronic social instability stress. Behav Brain Res. 2017;335.

12. Hirschfeld RM. History and evolution of the monoamine hypothesis of depression. J Clin Psychiatry. 2000;61 Suppl 6:4-6.

13. Blanchard DC, Cholvanich P, Blanchard RJ, Clow DW, Hammer RP, Rowlett JK, Bardo MT. Serotonin, but not dopamine, metabolites are increased in selected brain regions of subordinate male rats in a colony environment. Brain Res. 1991;568(1-2):61-6.

14. Xing Y, He J, Hou J, Lin F, Tian J, Kurihara H. Gender differences in CMS and the effects of antidepressant venlafaxine in rats. Neurochem Int. 2013; 63(6):570-5.

15. Stahl SM. Stahl's Essential Psychopharmacology: Neuroscientific Basis and Practical Applications. 4. edizioa. Cambridge: Cambridge University Press; 2013. 608.

16. Kalueff A V, Minasyan A, Keisala T, Shah ZH, Tuohimaa P. Hair barbering in mice: implications for neurobehavioural research. Behav Processes. 2006; 71(1):8-15.

17. Slattery DA, Cryan JF. Modelling depression in animals: at the interface of reward and stress pathways. Psychopharmacology. 2017;234(9-10):1451-65.

18. Garner JP, Weisker SM, Dufour B, Mench JA. Barbering (fur and whisker trimming) by laboratory mice as a model of human trichotillomania and obsessive-compulsive spectrum disorders. Comp Med. 2004;54(2):216-24.

19. Eskelund A, Li Y, Budac DP, Müller HK, Gulinello M, Sanchez C, Wegener G. Drugs with antidepressant properties affect tryptophan metabolites differently in rodent models with depression-like behavior. J Neurochem. 2017;142(1):118-31.

20. Jackson HC, Needham AM, Hutchins LJ, Mazurkiewicz SE, Heal DJ. Comparison of the effects of sibutramine and other monoamine reuptake inhibitors on food intake in the rat. Br J Pharmacol. 1997;121(8):1758-62. 21.

21. Thomson P. Physician's Desk Reference. 58. edizioa. Motvale; 2004. 3413-3424.

22. Czéh B, Fuchs E, Wiborg O, Simon M. Animal models of major depression and their clinical implications. Prog Neuro-Psychopharmacology Biol Psychiatry. 2016;64:293-21n 